\title{
PIGU wt Allele
}

National Cancer Institute

\section{Source}

National Cancer Institute. PIGU wt Allele. NCI Thesaurus. Code C52025.

Human PIGU wild-type allele is located in the vicinity of $20 q 11.22$ and is approximately $117 \mathrm{~kb}$ in length. This allele, which encodes phosphatidylinositol glycan anchor biosynthesis class U protein, plays a role in glycosylphosphatidylinositol (GPI) anchor biosynthesis. 